\title{
Dating late Miocene marine incursions across Argentina and Uruguay with Sr-isotope stratigraphy
}

\author{
Claudia J. del Río ${ }^{1}$, Sergio A. Martínez ${ }^{2}$, John M. McArthur ${ }^{3}$, \\ Matthew F. Thirlwall ${ }^{3}$, Leandro M. Pérez ${ }^{4}$
}

\footnotetext{
${ }^{1}$ Museo Argentino de Ciencias Naturales B. Rivadavia. A. Gallardo 470 (C1405DJR) Buenos Aires, Argentina (Phone=54 114982 6670)

${ }^{2}$ Facultad de Ciencias. Departamento de Evolución de Cuencas. Universidad de la República. Iguá 4225. (11400) Montevideo, Uruguay (Phone= 598 25252646)

${ }^{3}$ Earth Sciences, University College London, Gower Street, London WC1E 6BT, United Kingdom

${ }^{4}$ Museo de La Plata, 1900 La Plata, Argentina.
}

Corresponding author: Claudia J. del Río

Address: Museo Argentino de Ciencias Naturales B. Rivadavia. A. Gallardo 470 (C1405DJR) Buenos Aires, Argentina (Phone=54 114982 6670). claudiajdelrio@gmail.com 


\section{Abstract}

A Miocene Sr-isotope chronostratigraphy of the sedimentites deposited by the "Paranense" Sea along a NE-SW transect stretching for $1200 \mathrm{~km}$ along the southwestern Atlantic coast is performed herein. Determined numerical ages are presented and discussed for shells of Aequipecten paranensis from the Argentinean Puerto Madryn Formation, Facies Balneario La Lobería, “Entrerriense Beds” of the Salado Basin, and Paraná Formation, and from the Camacho Formation (Uruguay). The ${ }^{87} \mathrm{Sr} /{ }^{86} \mathrm{Sr}$ ages fall into five age-groups that embrace the "Paranense" flooding in the latest Serravalian-Messinian interval. For the Puerto Madryn Formation, the ages span the latest Serravalian to the Tortonian and are stratigraphically coherent with the Transgressive Phase (11.90-10.37 Ma) and the Regressive Phases (10.22-9.82 Ma and 9.40-9.05 Ma) of that unit. Ages of 8.85-7.95 Ma for the ¿Entrerriense Beds” show them to be Tortonian and the Facies Balneario La Lobería, and the Paraná and Camacho formations span the age-range 7.50-6.0 Ma, comprising the TortonianMessinian interval. These ages allow correlation of the base of the Barranca Formation with the Regressive Phase of the Puerto Madryn Formation and its middle horizons with the Facies Balneario La Lobería. The "Entrerriense Beds" are correlated with the "Beds of Cabo Buentiempo". Dating the "Paranense" marine incursion permits a reappraisal of its paleogeography and to differentiate their deposits from those of the "Patagoniense" Sea. The flooding surface was more reduced than previously thought being its northwesternmost limit in the surroundings of the Santa Fe Province and its southernmost boundary in southern Santa Cruz Province. Moreover, our results proved that the Paranaian Molluscan Bioprovince was coeval with the Valdesian Molluscan Bioprovince for $2.35 \mathrm{Ma}$ and that the species that constituted the Aequipecten paranensis Zone lived for at least 5.9 Ma .

Keywords: Sr-isotope; “Paranense” Sea; late Miocene; Paleogeography; Argentina; Uruguay 


\section{1-Introduction}

Neogene marine rocks exist along the Southwestern Atlantic coast, where are recorded in narrow areas along the coast that stretch from Southern Argentina to Southeastern Brazil. In Argentina, at least two major transgressions are recorded (Figure 1A-B). The oldest, termed the "Patagoniense" Sea, occurred from the late Oligocene to the earliest middle Miocene times and deposited in Eastern Patagonia the sedimentites included today into the Monte León, Carmen Silva, Chenque and Gaiman Formations. A later transgression, termed the "Paranense” or "Entrerriense” Sea, mostly developed in the late Miocene, and its deposits are identified, from north to south, as Camacho Formation (Department of Colonia, Uruguay), and in Argentina as Paraná Formation (Entre Ríos Province), “Entrerriense” Beds (Salado Basin, subsurface of the Buenos Aires Province), Facies Balneario La Lobería (Río Negro Province) and Puerto Madryn Formation (Chubut, Province). The deposits of this transgression also include the "Beds of Cabo Buentiempo" (Santa Cruz Province), recently dated as late Miocene (del Río et al., 2013) (Figure 2). Each of these "Paranense" units contains a well-documented molluscan assemblage (del Río, 1992, 1994; del Río and Martínez, 1998) that, since the middle of the $19^{\text {th }}$ century, has been diagnostic of "Paranense" rocks and assigned to the Aequipecten paranensis Zone by del Río (1988).

Although those Neogene horizons have largely called the attention of naturalists, through a dearth of accurate dates independent of biostratigraphy, many authors regarded some sedimentites of the "Patagoniense" Sea (i.e. (Monte León, Carmen Silva, Chenque and Gaiman Formations) as having been deposited by the "Paranense" transgression (Windhaussen,1931; Yrigoyen, 1975; Uliana and Biddle 1988; Ramos and Alonso, 1995; Aceñolaza and Aceñolaza, 1999; Sprechmann and Aceñolaza 1999; Malumián, 1999; Alonso, 
2000; Marengo, 2000; Aceñolaza and Sprechmann, 2002; Hernandez et al.. 2005; Malumián and Nañez, 2011).

The numerical ages of 9.41 Ma and 10.1 Ma obtained by Zinsmeister et al. (1981) and Scasso et al. (2001) respectively, placed the Puerto Madryn Formation in the late Miocene, but this dating was overlooked by some authors who suggested ages ranging from 15 to $5 \mathrm{Ma}$ (Hernandez et al., 2005) or from 15 to 9 Ma (Marengo, 2015) for the "Paranense" transgression.

Controversy also surrounds the area covered by this sea. Some geologists extended it to Northwestern and Western Argentina, but age of those sediments and whether they are even marine, are still matter of discussion. Correlation of those supposedly "Paranense" sediments with the middle Miocene Yecua Formation (southern Bolivia) (Marshall, 1993; Webb, 1995; Räsänen et al., 1995; Hernandez et al., op.cit.; Hovikosky et al., 2007; Uba et al., 2009; Hulka et al., 2006) has been used to support the idea of Ihering (1927) and Boltovskoy (1991) who suggested that a major seaway (e.g.“-Paranense” Sea) crossed South America in the Miocene, connecting Southwestern Atlantic Ocean with the Caribbean Sea. However, a marine origin of the Yecua Formation, and so the reality of the intra-continental seaway is not universally accepted (e.g. Nuttall, 1990; Nicolaides and Coimbra, 2008; Tineo et al., 2015). See Gross et al. (2015) for a review of the matter. In reference with the southern limit of the "Paranense" Sea, some authors placed it a few kilometers south of the valdés Penimente (Camacho, 1967; Scasso and del Río, 1987; del Río, 2000; Bellosi, 1995; Cione et al. 2011; Cuitiño et al., 2017), whilst others, because of considering sedimentites, of the "Patagoniense"Sea as deposited by the "Paranense" Sea, extended its boundary to the southernmost tip of Argentina.

As doubts persist still today concerning age and paleogeography of the "Paranense", we have undertaken further dating of putative "Paranense" deposits along the Southwestern 
Atlantic region in order to help resolve the uncertainty. We also review the correlation of the coastal "Paranense" units with sediments of Western and Northwestern Argentina previously thought to have been deposited or related with the "Paranense" Sea.

\section{Previous works}

Since the discovery of the "Paranense" sedimentites and the description of their molluscs by d'Orbigny (1842) and Darwin (1846), age of those rocks deserved most of the attention of geologists and paleontologists. Timing of the transgression as well as the correlation among the "Paranense" deposits have been the focus of controversies for a long time.: Below, it will be summarized previous ideas dealing with ages of the "Paranense" lithostratigraphic units.

2.1- Puerto Madryn Formation.- Sedimentites of this unit crop out around the city of Puerto Madryn and Península Valdés, northwards to Puerto Lobos (Cueva Los Leones ša area) (Chubut Province) (Figure 1D). Initially described by Ameghino (1890), Frenguelli (1926) and Feruglio (1949) in Península Valdés, these rocks and their molluscan faunas have been the center of detailed systematic and stratigraphic analyses, as well as paleoenvironmental and taphonomic interpretations (Scasso and del Río, 1987; del Río, 1991, 1992, 1994: del Río et al., 2001 Dn account of its fossiliferous content, the Puerto Madryn Formation has been placed in the Miocene s. l., middle Miocene or late Miocene. Del Río (1988) firstly assigned the formation a middle Miocene age based on the dominance of the typical Caribbean taxa of the Gatun Formation. This proposal was adopted by Malumián (1999), Malumián and Nañez (2011), Aceñolaza and Aceñolaza (1999), Aceñolaza (2000), and by Aceñolaza and Sprechmann (2002). Subsequently, those Caribbean faunas were placed in the late Miocene according to the associated foraminiferal assemblages (see discussion in Martínez, 1994) and 
since then a late Miocene age was accepted by del Río (2000) and Martínez and del Río (2002).

On vertebrate evidence, Cione and Tonni (1981) assigned it to the late Miocene, while Cozzuol et al. (1993), Cozzuol (1996), and Riva Rossi (1997) placed it in the middle Miocene. Subsequent refinements allowed age discrimination within the unit. Cione et al. (1996) and Azpelicueta et al. (2015) suggested a middle Miocene age for the Highstand Phase exposed at Puerto Pirámides and Cione et al. (2005a) recognized the Huayquerian Stage in the uppermost beds that crop out at the surroundings of Punta Delgada (Regressive Phase), estimating that those horizons should be considered younger than 9 Ma. A late Miocene age for the same beds was also supported by Dozo et al. (2010) (and bibliography therein). In later work, a probable middle Miocene age for the lower and middle horizons of the Puerto Madryn Formation was suggested by Cione et al. (2011).

Palynomorphs and foraminifera place this unit in the late Miocene (Palazzesi and Barreda, 2004; Marengo, 2015) while dinoflagellate cysts recovered from the Highstand Phase at Puerto Pirámides would indicate a Serravalian-Tortonian age (Fuentes et al., 2016).

These assignments of age were superseded by numerical dating. Zinsmeister et al. (1981) reported ${ }^{40} \mathrm{~K} /{ }^{40} \mathrm{Ar}$ ages 9.11+0,1 Ma; $9.56 \pm$ 0,3 Ma; $9.55 \pm$ 0,3 Ma (mean 9.41 Ma) for three glass concentrates from tuffs at the top of the Bahía Cracker section (Regressive Phase). Later, Scasso et al. (2001) obtained an ${ }^{87} \mathrm{Sr} /{ }^{86} \mathrm{Sr}$ age of $10 \pm 0.3$ Ma for shells of the scallops "Chlamys" actinodes and Chesapecten crassus, placing the Transgressive and the lower part of the Regressive phases in the middle Tortonian.

2.2- Facies Balneario La Lobería.- The marine horizons at the base of the cliffs situated between Bahía Rosas and Punta del Faro (northern littoral of San Matías Gulf, Río Negro Province; Figure 1 C) were described by De Ferraris (1966) and Angulo and Casamiquela (1982). The latter provided detailed lithological descriptions and placed them in the Facies 
Balneario La Lobería Angulo and Casamiquela (op.cit.), intercalation in the continental Río Negro Formation. It has been considered of late Miocene, late Miocene-early Pliocene or Pliocene age, depending on the mammal age assignment of the Río Negro Formation (Farinati et al., 1981; Angulo and Casamiquela, 1982; Echevarría, 1988; Pascual et al., 1996; see discussion in del Río et al., 2013). In these marine sedimentites, del Río (1988) recognized the Aequipecten paranensis Zone and suggested they are of late Miocene age (del Río, 2000).

2.3-“Entrerriense” Beds.- This name was given by Tapia (1937) to sediments deposited by the "Paranense" transgression in the Salado Basin (subsurface of the Ciudad Autónoma de Buenos Aires). They were considered of late Miocene (Yrigoyen, 1970) or middle-late Miocene age (Yrigoyen, 1975). Foraminiferal assemblage suggests a late Miocene-early Pliocene age (Malumián, 1970), but later works restricted it to the middle Miocene (Malumián and Nañez, 1996; Malumián, 1999). According to its calcareous nannoplancton content, Marengo and Concheyro (2001) and Marengo (2015) proposed a middle Miocene (Serravalian) age.

2.4- Paraná Formation.- This formation is exposed around the cities of Paraná and Diamante (Entre Ríos Province). On account of its microfaunistic content it was placed in the late Miocene (Rossi de García, 1966; Zabert and Herbst, 1977; Zabert, 1978; Herbst and Zabert, 1987), and according to its molluscan assemblage was firstly situated in the middle Miocene (del Río, 1991), which was followed by Aceñolaza and Aceñolaza (1999) and Aceñolaza (2000), and it was later given a late Miocene age (Martínez, 1994; del Río, 2000; Martínez and del Río, 2005). On vertebrate evidence it is ?middle Miocene-late Miocene 146 (Cione et al., 2008) and later refined to be late Miocene (Cione et al., 2000, 2005 b, 2011, Miocene (9.47 Ma) (Pérez, 2013). 
2.5- Camacho Formation.- This unit is exposed on the southern littoral of the Colonia

Department (Uruguay). Molluscs, selachians and mammals indicate that it should be placed in the late Miocene (Figueiras and Broggi, 1971, 1973; Martínez, 1994; 1998a; Martínez and del Río, 2002; Perea and Ubilla, 1989, 1990; Perea, 2005; Perea et al., 1994; 2013). An age of 17 Ma - 18 Ma was obtained by Sprechmann et al. (2010) using Sr-isotope stratigraphy, on two species of oysters, placing the formation in the early Miocene.

\section{Geological Setting} horizon represented by up to $3 \mathrm{~m}$ thick, medium and fine, ochreous sandstones, that grades upwards to a multi-event shell-supported bed, where Aequipecten paranensis is associated to

Studied deposits of the "Paranense" Sea include: surroundings of the city of Puerto Madryn, Península Valdés and Cueva Los Leones (Puerto Madryn Formation, Chubut Province), Balneario La Lobería (Facies Balneario La Lobería) (Viedma, Río Negro Province), the drill-hole Riachuelo IV (“Entrerriense” Beds, Salado Basin, Ciudad Autónoma de Buenos Aires), and sedimentites exposed near the cities of Paraná and Diamante (Paraná Formation, Entre Ríos Province). Sedimentary deposits of the "Paranense" Sea are also recognized in Uruguay at Cantera Geymonat (Colonia Department). Figure 3 illustrates lithological sections exposed at the mentioned localities.

3.1. Península Valdes.- Samples dated here come the Puerto Madryn Formation exposed

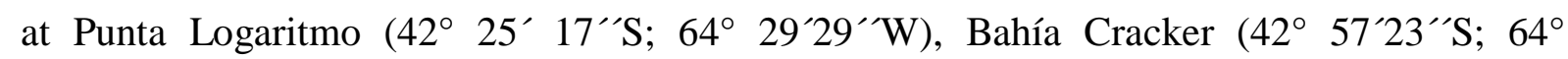

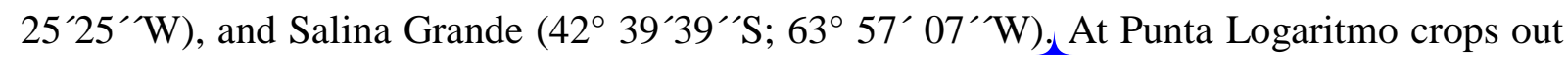
the Transgressive Phase of the unit overlaying whitish tuffaceous sandstones of the Gaiman Formation (middle Miocene). Samples for dating were collected from the only fossiliferous Crassostrea patagonica, Cubitostrea alvarezi, “Chlamys” actinodes, Pachymagas 
174 piramidesia and Turritella piramidesia. Fossils are abundant, and bivalves are disarticulated and well preserved (Figure 4-F).

Lithological section at Salina Grande corresponds to the Regressive Phase of the Puerto Madryn Formation and comprises intercalations of muddy heterolitic or massive, bioturbated very fine sandstones, fine bioturbated sandstones and up to a $0,8 \mathrm{~m}$ thick, medium to fine multi-event, shell-supported beds with erosive lower and upper planar contacts. Aequipecten paranensis is associated to Amusium paris, Crassostrea patagonica and Leopecten piramidesensis. (FIGURE 4 D-E)

At Bahía Craker, the upper part of the Regressive Phase of the Puerto Madryn Formation is exposed as $30 \mathrm{~m}$ thick - of intercalated of gray heterolitic mudstones and very fine sandstones with fossiliferous, cross-bedded, fine sandstones where fossils are usually broken except for the uppermost tuffaceous sandstones that containes shell-beds where Aequipecten paranensis is associated to oysters and Monophoraster darwini.

3.2. Cueva Los Leones- Miocene marine fossiliferous sedimentites are recorded 66,5 km north to the city of Puerto Madryn, and $25 \mathrm{~km}$ southwest from Puerto Lobos (Chubut Province). Exposures consists of a narrow strip that stretches over 33 kilometers between $42^{\circ}$ $17^{\prime} \mathrm{S}$ and $42^{\circ} 01^{\prime} \mathrm{S}$, along the western side of Highway, 3 . Cortes (1987) placed the basal beds in the Gaiman Formation and the upper horizons in the Puerto Madryn Formation. The measured section of the Puerto Madryn Formation (42 $12^{\prime} 30^{\prime \prime}$ S and $65^{\circ} 20^{\prime} \mathrm{W}$ ) comprises a sequence of up to $22 \mathrm{~m}$ thick of cross-bedded or laminated, fairly loose, very fine and fine gray sandstones, and four 1,5 m thick shell-beds constituted by ochreous, fine or very fine sandstones. Those shell-beds contain a rich invertebrate fauna which varies laterally from well-preserved to highly fragmented accumulations. The fossiliferous assemblage contains dense accumulations of Aequipecten paranensis, Cubitostrea alvarezi and Crassostrea patagonica, co-occurring with scarce Monophoraster darwini, Pachymagas piramidesia, rare 
Trophon sp. and isolated vertebrate remains. Capping the sequence there is $0.8 \mathrm{~m}$ thick of gray cross-bedded sandstones bioturbated with Skolitos and Ophiomorpha.

3.3- Balneario La Lobería.- The section is exposed at $41^{\circ} 09^{\prime} 18.80^{\prime \prime} \mathrm{S}-63^{\circ} 07^{\prime} 28.84^{\prime \prime}$ $\mathrm{W}$, some $40 \mathrm{~km}$ southwest of the town of Viedma and $225 \mathrm{~m}$ to the east of the staircase down to the beach of the Balneario La Lobería. At the base of the section is 1 meter laminated very fine sandstones followed by 2 meters of barren ochreous, cross-stratified medium sandstones, overlain by $7 \mathrm{~m}$ thick, yellowish, massive, fine sandstones that contain three loosely packed fossiliferous horizons. The lowermost, of 1,5 metres thick $k_{2}$ was sample for Sr-isotope stratigraphy and contains concentrations of exceptionally well-preserved both disarticulated and articulated shells of Aequipecten paranensis, Ostrea sp and Pododesmus camachoi. Laterally, this association is replaced by molds of Chionopsis sp., Ameghinomya sp, and Anadara sp. This bed is capped by a $10 \mathrm{~cm}$ thick horizon, composed mostly of well-preserved Monophoraster darwini in life position and bunches of articulated oysters lying on the left valve. The second and third shell-beds comprise disarticulated and chaotically dispersed valves of Ostrea sp. The Río Negro Formation, which overlies the Facies Balneario La Lobería, is represented by 53.5 m of bluish gray, medium and fine cross-stratified sandstones, capped by a highly bioturbated, massive and compact white siltstones of 0,5 $\mathrm{m}$ thick (Figure 4 A-B).

3.4. Drill-hole Riachuelo IV.- Drilled by the Dirección Argentina de Minas y Geología, this core recovered $280 \mathrm{~m}$ of the "Entrerriense Beds” at Puente Pueyrredón (34 39`23”S, $\left.58^{\circ} 22^{\prime} 13^{\prime \prime} \mathrm{W}\right)$. The section is mainly composed of ochreous-reddish or greenish mudstones, with fine and medium sandstones intercalated at its base. Two fossiliferous beds are located between 44.8 - 54.40 mbgs and 68.10 - 72.70 mbgs. Shells of $A$. paranensis come from the lower and are associated to Chionopsis muensteri, Crassatella suburbana, Anadara lirata, 
223 Amusium darwinianum and abundant bryozoans. Capping this section there are the Quaternary “Puelchense” beds.

3.5- Paraná and Punta Gorda.- Specimens of Aequipecten paranensis that we have dated were collected by B. Bicego in 1892 and A. Bravard between 1854 and 1856 from isolated exposures of the Paraná Formation along the left bank of the Paraná River, in the city of Paraná, and by C. del Río and L. Pérez in Punta Gorda Sur (Diamante, 3204`15”S, $\left.60^{\circ} 39^{\prime} 11^{\prime \prime} \mathrm{W}\right)$. In Punta Gorda there is a small outcrop, 2,5 m thick that comprises from base to top, an intercalation of gray laminated, very fine sandstones and mudstones, followed by a massive poorly fossiliferous medium sandstone. The section is capped by an amalgamated ochreous, compact, shell-bed that reaches up to $30 \mathrm{~cm}$ thick that contains Anadara bonplandeana, Glycymeris minuta, Crassostrea cf. rhizophorae, Crassostrea patagonica, Cubitostrea alvarezii, Aequipecten paranensis, Leopecten oblongus, Miltha iheringiana?, Venericardia crassicosta, Dinocardium platense, Mactra bonariensis?, Chionopsis munsterii, and abundant bryozoans (Perez, 2013) (Figure 4 I-J).

3.6. Cantera Geymonat (Uruguay).- Dated shells come from the Camacho Formation exposed at Cantera Geymonat ( $34^{\circ} 25^{\prime} 57^{\prime \prime} \mathrm{S}$; $\left.57^{\circ} 49^{\prime} 0.6^{\prime \prime} \mathrm{W}\right)$, near the city of Colonia del Sacramento. The exposures have a reduced areal extension, and consist of a thin basal conglomeradic sandstones with abundant oysters. This is overlain by $3 \mathrm{~m}$ thick of tuffaceous sandstones that grade upwards to highly fossiliferous, loose, fine sandstones containing a concentration of oysters associated with few terebratulids, balanids, Pododesmus sp., Trophon sp and Aequipecten paranensis. Capping the section there are barren fine sandstones (Figure 4 H).

\section{Material and Methods}


Twenty samples of Aequipecten paranensis have been dated by Sr- isotope stratigraphy

(Table 1). Specimens were cleaned of adhering matrix by physical abrasion coupled with brief agate pewstle-and-mortar, cleaned again by immersion for a few seconds in dilute nitric acid, washed with $18 \mathrm{M} \Omega$ water, and dried in a clean environment. The best preserved fragments were picked under the microscope to select $10 \mathrm{mg}$ of thin, sheet-like, fragments that were the best preserved. The diagnostic features of good preservation are fragmentation along the original layering, clear calcite as fragments, and an absence of Fe or Mn stain. The picked samples were dissolved in nitric acid, evaporated to dryness, and $\mathrm{Sr}$ was separated using Eichrom Sr-spec resin.

Measurements of ${ }^{87} \mathrm{Sr} /{ }^{86} \mathrm{Sr}$ were made on a Phoenix Isotopx magnetic-sector thermalionization mass-spectrometer using Re filaments. Values of ${ }^{87} \mathrm{Sr} /{ }^{86} \mathrm{Sr}$ were normalized to an ${ }^{87} \mathrm{Sr} /{ }^{86} \mathrm{Sr}$ value of 0.1194 using exponential correction for fractionation. The long-term value of NIST987 measured before, during, and after the analysis of our samples was $0.710236 \pm$ 0.000007 (2s.d.) All values of ${ }^{87} \mathrm{Sr} /{ }^{86} \mathrm{Sr}$ reported in Table 1 have been normalised to a value for NIST987 of 0.710 248, which is equivalent to a value for EN-1 (modern seawater) of 0.709174.

Numerical ages were derived from ${ }^{87} \mathrm{Sr} /{ }^{86} \mathrm{Sr}$ ratios using the LOWESS calibration curve of McArthur et al. (2012). The uncertainties on the numerical ages are derived by compounding the uncertainty of measurement with the uncertainty on the LOWESS calibration line, and are shown in Table 1 as standard errors of the mean values. 


\section{Results and Discussion}

274

5.1- Age of the "Paranense" Sea.- Numerical ages presented here rounded to three significant figures, clustered into five age-group (Figure 5 A): 11.90-10.37 Ma (latest Serravalian- Tortonian); 10.22 - 9.82 Ma (Tortonian); 9.40- 9.05 Ma (Tortonian); 8.85-7.95 Ma (Tortoninan); 7.50-6.0 Ma (latest Tortonian- Messinian).

The three older age-are recorded in the Puerto Madryn Formation and represent both the Transgressive, and the entire Regressive phases of this unit. The oldest ages occur in the basal beds exposed at Cueva Los Leones, which is correlative with the Transgressive Phase at Punta Logaritmo. Ages 10.22-9.82 Ma corresponds to the middle portion of Regressive Phase at Salina Grande, and the youngest of the three (9.40 to $9.05 \mathrm{Ma}$ ) to the upper Regressive Phase at Bahía Cracker. This age range was obtained on shells from the top of the unit at Bahía Cracker and are similar to the 9.40 Ma using ${ }^{40} \mathrm{~K} /{ }^{40} \mathrm{Ar}$ determined by Zinsmeister et al. (1981), for samples coming from the same beds sampled in this paper.

Previous numerical dating of the Puerto Madryn Formation by Scasso et al. (2001) was insufficiently precise to discriminate ages of the basal, middle and upper parts of the unit which represent a complete transgressive-regressive cycle. The mean age given by those authors was $10.0 \pm 0.3 \mathrm{Ma}$ and comes from 1 )- lowest beds belonging to the Transgressive Phase, exposed at Eje Tentativo and El Doradillo; 2)- horizons from the Maximum Flooding surface that crop out in the Puerto Piramide-Lobería'area, and in the upper section at Eje Tentativo; 3)- lowermost part of the Regressive Phase in Lobería Punta Pirámid (S) Fig( B). Our more precise determinations of ${ }^{87} \mathrm{Sr} /{ }^{86} \mathrm{Sr}$, made possibly by improved massspectrometry (VG 354 v Phoenix Isotopx), has reduced 2 s.d of external precision from \pm 0.000015 to 0.000006 . Moreover, the samples analyzed herein are preserved better than 
The results obtained herein suggest that the basal beds of the Transgressive Phase of the Puerto Madryn Formation must be placed in the latest Serravalian, and the overlying sedimentites in the Tortonian, which disagree with Cione et al. (2011), who estimated a middle Miocene age for the basal and middle part of the unit (i.e. Transgressive and Highstand Phases). It also precludes the Highstand Phase being Serravalian as suggested on dinoflagellates evidence (Fuentes et al., 2016). Besides, these results also permits correlation of the upper portion of the Puerto Madryn Formation (Regressive Phase) with the base of the Barranca Final Formation at its type locality, which has been dated in 9.61Ma (Palazzesi et al., 2014).

The fourth age-group (8.85 to $7.95 \mathrm{Ma}$, Tortonian) comprises the first numerical ages for the "Paranense" Sea in the Salado Basin and is stratigraphically concordant with the other sections that yield the Aequipecten paranensis Zone such as the Paraná and Camacho formations and Facies Balnerario La Lobería, and younger than the Serravalian age proposed by Marengo and Concheyro (2001) and Marengo (2015) on the basis of the calcareous nannoplancton NN5 Zone in the Riachuelo V drill-hole. This core is situated a few meters from Riachuelo IV and beds containing the NN5 Zone could be correlated with Riachuelo IV core. (Marengo, oral com.), but these drill holes are old and the discrepancy in age may be attributable to curation errors, since foraminifers and the Aequipecten paranensis Zone indicate a late Miocene age as our numerical dating do. “Beds of Cabo Buentiempo” recently dated by means of Sr-isotope stratigraphy as $8.95 \pm 0.82 \mathrm{Ma}$ and correlated with the upper part of the Puerto Madryn Formation (del Río et al., 2013), are now also correlated with the base of the "Entrerriense Beds" in the Salado Basin.

The youngest deposits (7.5-6.0 Ma) of the "Paranense" transgression comprise the Facies 

recently dated in 6.48 Ma (Palazzesi et al., 2014) and not coeval with the section the

Highstand of the Puerto Madryn Formation, as proposed by those authors. The finding of a

typical open marine molluscan assemblage (including Aequipecten paranensis, Glycymerita magna, Ameghinomya argentina, "Chlamys" actinodes and Turritella pyramidesia) in the lower and upper fossiliferous beds of the Barranca Final Formation, firstly reported herein, corroborates the presence of the "Paranense" Sea along the entire northern littoral of the San Matías Gulf extending northwards to reach the Salinas del Gualicho’s area. Messinian) based on five samples, is much younger than 9.47 Ma provided by Pérez (2013) through Sr-isotope stratigraphy from a single valve of Leopecten oblongus. The age discrepance may result from differences in preservational state; we have repeatedly found that altered samples have lower ${ }^{87} \mathrm{Sr} /{ }^{86} \mathrm{Sr}$ (and so older ages) than do well-preserved ones.

The age range of 7.20-6.0 Ma (Messinian) for the Camacho Formation is concordant with a late Miocene age for the unit suggested by Martínez (1994) and Martínez and del Río (2002) on the basis of molluscan assemblages. A date of 17 - 18 Ma obtained by Sr-isotope stratigraphy is given in an abstract by Sprechmann et al. (2010), but preservational assessment was lacking and we again suspect that the old age may be a feature of alteration. interval, disagrees from that of Hernández et al. (2005), who stated that the "Paranense" transgression spanned 15-5 Ma, and comprised two different events, i.e. at 15-13 Ma (middle 
event and the youngest one would have also reached West and Northwestern Argentina (see below).

5.2- Paleogeography of the "Paranense" Sea. As explained in the Introduction, some authors considered the Chenque, Monte León, Gaiman and Carmen Silva formations (FIGURE 1B; FIGURE 2) as deposited by the "Paranense" transgression and extended the area covered by that sea from the southernmost tip of Patagonia to Northwestern Argentina. Our new dating along with those obtained for the sedimentites of the "Patagonian" Sea (Parras et al. 2012, Cuitiño et al., 2015) and the biostratigraphic information based on palynomorphs and molluscs (Barreda and Palamarczuk, 2000; del Río, 2004) allow to constrains it to the $22 \mathrm{Ma}-18 \mathrm{Ma}$ interval (Parras et al., 2012). There is no numerical dating 
372 Olivero (2006) considered it of middle Miocene and correlated it with the "Entrerriense” (= 373 "Paranense”) Sea.

374 On one hand, the new ages obtained in this paper show that the oldest marine rocks of the "Paranense” Sea were deposited during the latest Serravalian, whilst most of the transgression occurred during the Tortonian-Messinian interval, being in this way, younger than the 377 "Patagoniense" Sea. On the other hand, while the sedimentites of the "Paranense" Sea are clearly characterized by the Aequipecten paranensis Zone, the Gaiman, Chenque, Monte León and Carmen Silva formations are identified by remarkable different molluscan associations. For reasons given above, it is unlikely that sedimentites underlying the Puerto Madryn Formation were deposited by the "Paranense" transgression. Until now, no latest middle or late Miocene marine horizons have been recognized south of the city of Trelew, except for the geographically isolated Tortonian incursion of the sea detected in the latitude of Río Gallegos where the "Beds of Cabo Buentiempo" are exposed in a very reduced area.

5.2.2- Northern extension.- Whether the "Paranense" Sea extended into Northwest and West Argentina is still a controversial issue. Roth (1908) was the first author to propose the presence of open marine facies correlated with that sea in Santiago del Estero Province whilst Stappenbeck (1926) did so for Catamarca Province, where it would have been represented by brackish facies. Windhaussen (1931) carried out the first paleogeographic reconstruction of the sea, showing it extending from the southernmost tip of South America northwards to Paraguay. Since then, few changes have been made to its areal extent except for the addition of some minor incursions of the sea into Mendoza and San Juan provinces (Groeber, 1949; Yrigoyen, 1993; Pérez and Ramos, 1996). Units exposed in Northwest and West Argentina are the continental Anta, Del Buey, Chinches and San José formations, and the carbonatic beds intercalated in them were thought to have had a marine origin related to the presence of the "Paranense" Sea, or to an hipersaline lagoon permanently or sporadically connected with 
that sea (Russo and Serraioto, 1978; Cione et al., 1995; Quatrocchio et al., 2003; Davila and Astini, 2002; Ottone et al., 1998; Hernandez et al., 2005). The age of those units are undoubtly middle Miocene (Reynolds et al., 2000; Davila, 2005; Jordan et al., 1996; Gavriloff and Bossi, 1992) and the analysis of Ruskin et al. (2011), bring to an end the idea of the presence of any marine influence in West and Northwest Argentina. Among other aspects, and due to the ratio of sable these authors demonstrated that the carbonatic strata are of lacustrine origin, concluding that the "Paranense" marine incursion would have never reached those regions of Argentina, rejecting any marine connection between the Caribbean Sea and the South Atlantic Ocean.

The San José Formation, exposed in the Santa María Valley (Tucumán and Catamarca provinces) was not included by Ruskin et al (op.cit.) in their analysis. The diagenetic aspects of the ostracod Cyprideis herbsti, and the foraminifers Streblus parkinsoniana and Streblus compactus found at the base of the San José Formation, led to Bertels and Zabert (1980) to infer the presence of a lagoon with high salinities directly connected with the "Paranense" Sea, an idea later followed by Bossi and Palma (1982). Gavriloff and Bossi (1992) also claimed for an obvious relationship between this microfauna and the "Paranense" transgression, but they concluded that the San José Formation "would not represent a typical marine sequence or if so, it would have been soon stopped being one” (p.28). Later, Gavriloff (1999) and Bossi et al. (1999) proposed for this unit a paralic environment related to the “Paranense” Sea.

Chaia (in Vergani et al., 1991), Leiva and Morton (2001) and Espíndola (2004) increased the number of foraminifer and ostracod species of the San José Formation. According to the nomenclature used in those papers, the foraminifers are: Ammomia beccari parkinsoniana (= tuberculatum, Trochammina sp., Streblus compactus, and the ostracods are: Cyprideis 
422 herbsti, Cyprideis cf. torosa, Cyprideis salebrosa, Darwinula sp., Perissocytheridea sp.,

423 Limnocythere sp., Cyprinotus cingalensis, and Cyamocytheridea ovalis. Chaia (op.cit.)

424 considered the microfauna as a Late Miocene assemblage of Atlantic origin, and distinguished

425 three transgressive episodes in the base of the formation.

426 Except for those provided by Bertels and Zabert (1980), there are no illustrations of the

427 microfossils mentioned above, making difficult any evaluation. Some taxa are extinct, others

428 are not useful as paleoenvironmental indicators, e.g. P. tuberculatum is tolerant to brackish waters (Malumián, 1978) or to open marine environments, as it is demonstrated by their presence in the Puerto Madryn Formation (Marengo, 2015) where is associated to a molluscan assemblage of normal salinity (del Río, 1992; 1994). The species Nonion demens can be restricted to brackish environments (Boltovskoy, 1991). Among extant species, Buccella frigida is tolerant to low salinities (Boltovskoy and Wright, 1976), and A. beccari parkinsoniana can either inhabits in fresh environments with intermittent influence of brackish waters, as happens in ta Plata Rive, in lagoons with influx of fresh waters (Boltovskoy and Boltovskoy, 1968; Boltovskoy and Lena, 1971; Boltovskoy and Wright, op.cit.) or present in the Puerto Madryn Formation (Marengo, op.cit.) In reference to the ostracods, Cyprideis herbsti is an endemic taxa, C. salebrosa is a limnic to oligohaline species (up to 5 psu; Keyser, 1977), and C. cingalensis is a freshwater inhabitant (Eagar 2000; Karanovic, 2008). In some cases, the microfauna associated with freshwaters gastropods, carophytes and bones remains (Herbst et al., 2000). Moreover, there is a strong abundance 442 and diversity decrease of the microfaunas towards northwestern region, being dominated by 443 only two species typical of stress environments ( $P$. tuberculatum and A. parkinsoniana) 444 (Marengo, 2000). Regarding molluscs, there is no evidence of open marine species in the San José Formation as those recorded in easternmost exposures (i.e. Paraná and Puerto Madryn 
446 formations, and "Entrerriense Beds" of the Salado Basin), but instead, microfaunas are associated with fresh water molluscs (Herbst et al., 2000; Morton and Herbst, 2003).

In consequence, the idea of any marine incursion in the Tucumán and Catamarca provinces cannot be supported. Even if the base of the San José Formation would have been deposited in brackish environments, it should be expected the presence of a sea close to the area (i.e. Santiago del Estero Province) where, until now, it was not found any other unequivocally evidence of open marine conditions, but it was recorded a low diversified and scarce microfauna (Zabert, 1978; Herbst and Zabert, 1987; Marengo, 2015). Last, but not least, even in the improbable case that will be proved in the future the development of an unequivocally marine microfauna in the middle Miocene San José Formation, the inference of a elose sea to the area should not be related any more to a late Miocene sea, but with an older transgression of middle Miocene age. In this way, the westernmost limit of the "Paranense" Sea would have reached the Santa Fé Province such it is demonstrated by the still moderate high diversity of foraminifers in this region.

5.3.- Late Miocene Bioprovinces and long-term living species- Martínez and del Río (2002) defined the late Miocene Molluscan Valdesian and the Paranaian bioprovinces. According to the numerical Sr-ages presented herein, the Valdesian province existed between about 11.9-6.5Ma while the Paranaian one between 8.85 and $6 \mathrm{Ma}$, having little overlap in time (2.35Ma). Compared with the duration of other late Paleogene-Neogene Tertiary bioprovinces such as those defined by Petuch $(1988$; 2014) for the Western Atlantic and Eastern Pacific, the Valdesian and Paranaian provinces have lasted for a considerable shorter time.

The present analysis also contributes to assess the duration of species that were restricted to the Aequipecten paranensis Zone as A. paranensis itself, Anomalocardia entrerriana, Anadara bomplandeana, Epitonium borcherti, Calliostoma bravardi and Trophon leanzai. 
471 These taxa are widely distributed in each one of the studied region, and demonstrate to have

472 lived at least during 5.9 Ma which is in accordance to the mean values for duration of 473 molluscs proposed by Crampton et al. (2010). The time-life elapsed for those late Miocene 474 species is even shorter when compared with the long-living taxa associated, such as 475 Ameghinomya argentina, A. meridionalis, Dosinia meridionalis, Crassatella kokeni, Macoma 476 perplana, Tellina jeguaensis and Panopea regularis, which are present in the region since the early Miocene. The time range of the late Miocene species is also shorter in comparison with those taxa that survived from the late Miocene into modern times in the region: Leionucula puelcha, Felaniella vilardeboana Caryocorbula pulchella and Cyrtopleura lanceolata. Moreover, the flooding interval of the "Paranense" Sea, was time enough for the evolution to occur of closely related species such as Chionopsis australis, Amusium paris, Leopecten piramidesensis and Dosinia cuspidata (that lived at the beginning of the transgression) and the later taxa Chionopsis muensteri, Amussium darwinianum, Leopecten oblongus and Dosinia entrerriana.

\section{Conclusions}

1- Numerical dating by Sr-isotope stratigraphy shows that flooding time of the "Paranense" Sea elapsed from 11.9 to 6 Ma (latest Serravalian-Messinian), with sediments showing a

2- Numerical ages fall into five intervals: 1) 11.9-10.37 Ma; 2) 10.22-9.82 Ma; 3) 9.40general trend to be younger northwards. These dates are the first to be performed for the “Entrerriense” Beds” located in the Salado Basin, for the Facies Balneario La Lobería and the Puerto Madryn Formation exposed at Cuevas Los Leones.

$$
\text { 9.05 Ma; 4) } 8.85 \text {-7.95 Ma; and 5) 7.50-6.0 Ma. }
$$


3- The first three stratigraphically coherent, allow to discriminate the time of

496 deposition of the entire Puerto Madryn Formation at its type locality (Península Valdés

497 and surroundings of the city of Puerto Madryn). The lowest beds of the Transgressive

498 Phase belong the latest Serravalian and are correlated with the basal horizons of the unit

499 exposed at Cueva de Los Leones. The second and third intervals constrain the entire

500 Highstand and the Regressive phases to the Tortonian. The third interval coincides with

501 values obtained by Zinsmeister et al. (1981) through ${ }^{40} \mathrm{~K} /{ }^{40} \mathrm{Ar}$ who dated the same beds

502 than us, exposed at Bahía Cracker, which are herein correlated with the basal deposits of

503 the Barranca Final Formation.

504 4- The interval 8.8-7.95 Ma corresponds to the "Entrerriense” Beds deposited in the Salado

505 Basin, resulting younger than the previously proposed biostratigraphic age by means of 506 the nannoplancton content, and allow their correlation with the "Beds of Cabo 507 Buentiempo”, slightly younger than the uppermost strata of the Puerto Madryn Formation.

508 5- The youngest units clustered in the interval 7.50-6 Ma, correspond to the Facies 509 Balneario La Lobería, and the Paraná and Camacho formations. The numerical dating for 510 the Facies Balneario la Lobería (6.6-7.08 Ma), lead us to state the definitive relationship 511 between those sedimentites and the "Paranense" Sea, which is also corroborated by the 512 presence of the Aequipecten paranensis Zone. It also correlates with the middle strata of 513 the Barranca Final Formation at its type locality, where this zone has been recognized in 514 this paper

515 6- The Paraná Formation is 6.67-7.50 Ma (Messinian), being much younger than previously 516 thought.

517 7- Values obtained for the Camacho Formation are younger than those estimated by 518 Sprechmann et al. (2010), and their similarity with those obtained for the Paraná 519 Formation supports the proposal of Martínez (1989) that, in the frame of a global 

similitude, the Paraná and Camacho Formations are more related between them than to the Puerto Madryn Formation.

8- Neither the early Miocene -earliest middle Miocene marine sedimentites recorded in the Chenque Formation, nor the middle Miocene carbonate beds intercalated in the continental units of Western and Northwestern Argentina should be related with the latest

9- The maximum westwards extension of the "Paranense" Sea would have reached the Santa

\section{Acknowledgements}

The authors are in debt with M. Verde (Facultad de Ciencias, Universidad de La República,

540 Uruguay) for providing material and information dealing with Cantera Geymonat, with I.

541 Gavriloff (Universidad Nacional de Tucumán) for facilitating literature, and G. Buceta and H.

542 Marengo (Servicio Geológico y Minero Argentino, Argentina) for permitting access to 543 profiles performed in drill-hole Riachuelo IV reproduced herein. The present paper has been 
supported by PICT-ANPCyT 57, PIP-CONICET 320 (Argentina), CSIC 265 and PEDECIBA (Uruguay)

\section{References}

Aceñolaza, F.G. 2000. La Formación Paraná (Mioceno medio): estratigrafía, distribución regional y unidades equivalentes. In: Aceñolaza, F.G., Herbst, R. (Eds.) : El Neógeno de Argentina. Serie Correlación Geológica, 14: 9-27.

Aceñolaza, F.G., Aceñolaza, G.F. 1999. Trazas fósiles del Terciario marino de Entre Ríos (Formación Paraná, Mioceno medio), República Argentina. Boletín de la Academia Nacional de Ciencias, 64: 209-233.

Aceñolaza, F., Sprechmann, P. 2002. The Miocene marine transgression in the meridional Atlantic of South America. Neues Jahrbuch für Geologie and Paläontologie, 225: 75-84.

Alonso, R. 2000. El Terciario de la Puna en tiempos de la ingresión marina paranense. In: Aceñolaza, F.G. and Herbst, R. (Eds.): El Neógeno de Argentina. Serie Correlación Geológica, 14: 163 - 180.

Ameghino, C. 1890. Exploraciones geológicas en la Patagonia. Boletín del Instituto Geográfico Argentino, 11 (1): 2-46.

Angulo, R., Casamiquela, R. 1982. Estudio estratigráfico de las unidades aflorantes en los acantilados de la costa norte del golfo San Matías (Río Negro y extremo austral de Buenos Aires) entre los meridianos 62 $30^{\prime}$ y 64 30’. Mundo Ameghiniano, 2: 20-73.

Azpelicueta, M.M., Cione, A.L., Cozzuol, M.A., Miranda, J.M. 2015. Kooiichthys jono n. gen. n. sp., a primitive catfish (Teleostei, Siluriformes) from the marine Miocene of southern South America. Journal of Paleontology, 89: 791-801. doi:10.1017/jpa.2015.52. 
Barreda, V.D., Palamarczuk, S. 2000 Estudio palinoestratigráfico del Oligoceno tardío Mioceno en secciones de la costa patagónica y plataforma continental argentina. In F. G. Aceñolaza, F.G. and Herbst, R. (Eds.), El Neógeno de Argentina. Serie Correlación Geológica, 14:103-138.

Bellosi, E. 1995. Paleobiogeografía y cambios ambientales de la Patagonia central durante el terciario medio. Boletín de Informaciones Petroleras, 44: 50-83

Bertels, A., Zabert, L. 1980. Microfauna del Grupo Santa María (Terciario superior) en las Provincias de Catamarca y Tucumán, República Argentina. 2º Congreso Argentino de Paleontología y Bioestratigrafía y $1^{\circ}$ Congreso Latinoamericano de Paleontología, (Buenos Aires, 1978), Actas, 3: 67-73.

Boltovskoy, E. 1991. Ihering's hypothesis in the light of foraminiferological data. Lethaia, 24: 191-198.

Boltovskoy E., Wright, R. 1976. Recent Foraminifera. 515 pp. Junk, The Hague.

Boltovskoy, E., Boltovskoy, A. 1968. Foraminíferos y tecamebas de la parte inferior del río Quequén Grande, Provincia de Buenos Aires, Argentina (sistemática, distribución, ecología). Revista del Museo Argentino de Ciencias Naturales, Hidrobiología, 2 (4):127164.

Boltovskoy, E., Lena, H. 1971. The Foraminfera (except Family Allogromiidae) which dwell in fresh water. Journal of Foraminiferal Research, 1: 71-76.

Bossi, G. E., Palma, R. M. 1982. Reconsideración de la estratigrafía del valle de Santa María, provincia de Catamarca, Argentina. 5 Congreso Latinoamericano de Geología,. Actas, 1: 155-172.

Bossi, G.E., Muruaga, C.M., Gavriloff, I.J.C. 1999. Sierras Pampeanas. In: Gonzalez Bonorino, G., Omarini, R. and Viramonte, J. (Eds.): Geología del Noroeste Argentino. $14^{\circ}$ Congreso Geológico Argentino, Relatorio, 329-360. 
594 Camacho, H.H. 1967. Las transgresiones del Cretácico superior y Terciario de la Argentina. 595 Revista de la Asociación Geológica Argentina, 22: 253-280.

596 Cione, A.L., Tonni, E.P. 1981. Un pingüino de la Formación Puerto Madryn (Mioceno 597 tardío) de Chubut, Argentina. Comentarios acerca del orígen, paleoecología y la 598 zoogeografía de los Spheniscidae. $2^{\circ}$ Congreso Latinoamericano de Paleontología (Puerto Alegre), Anais, 591-604.

600

Cione, A.L., Vergani, G., Starck, D., Herbst, R. 1995. Los peces del Mioceno de la 601 Quebrada de La Yesera, provincia de Salta, Argentina. Su valor como indicadores ambientales y su antigüedad. Ameghiniana, 32, 151-157.

Cione, A.L., Azpelicueta, M.M., Caille, G. 1996. An ariid catfish (Osteichthyes: 604 Siluriformes) from marine middle Miocene beds of Patagonia. Recent ariid biogeography in southern South America. Revista Española de Paleontología 11 (10): 11-17.

606

607

608

609

610

611

612

Cione, A.L., Azpelicueta, M.M., Bond, M., Carlini, A.A., Casciotta, J.R., Cozzuol, M.A., de la Fuente, M., Gasparini, Z., Goin, F.J., Noriega, J.,Scillato-Yané, G.J., Zoibelzon, L., Tonni, E.P., Verzi, D., Vucetich, M.G. 2000. Miocene vertebrates from Entre Ríos province, Argentine. In: Aceñolaza, F.G.and Herbst,R. (Eds.): El Neógeno de Argentina. Serie Correlación Geológica, 14: 191-237.

Cione, A.L., Azpelicueta, M.M., Casciotta, J.R., Dozo, M.T. 2005a. Freshwater teleosts from Miocene beds of eastern Patagonia, southern Argentina. Geobios, 38: 29-42. $\underline{\text { doi.org/10.1016/j.geobios.2003.08.005 }}$

Cione, A.L., Casciotta, J.R., Azpelicueta, M.M., Barla, M., Cozzuol, M.A. 2005b. Peces marinos y continentales del Mioceno del área mesopotámica argentina, procedencia estratigráfica y relaciones biogeográficas. In: Aceñolaza, F.G. (Ed.): Temas de la Biodiversidad del Litoral Fluvial Argentino II. INSUGEO, Miscelánea, 14: 49-64. 
618 Cione, A.L., Mennucci, J. Perez, L., Barla. M.J. 2008. Megascyliorhinus trelewensis 619 (Neoselachii) in the ?Middle-Upper Miocene of Paraná, Central eastern Argentina. In: 620 Aceñolaza, F.G. (Ed.): Temas de la Biodiversidad del Litoral III, INSUGEO, Miscelánea, 17: 41-48.

622

Cione, A.L., Cozzuol, M.A., Dozo, M.T., Acosta Hospitaleche, C. 2011. Marine vertebrate assemblages in the southwest Atlantic during the Miocene. Biological Journal of the Linnean Society, 103: 423-440. doi:10.1111/j.1095-8312.2011.01685.x

Cione, A.L., Cabrera, D.A., Barla, M.J. 2012. Oldest record of the Great White Shark (Lamnidae, Carcharodon; Miocene) in the Southern Atlantic. Geobios, 45: 167-172. doi:10.1016/j.geobios.2011.06.002

Cione, A.L., Cabrera, D.A., Azpelicueta, M M. Casciotta, J.R., Barla, M.J. 2013. Peces del Mioceno marino y continental en Entre Ríos, oriente central de Argentina. In: Brandoni, D. and Noriega, J. I. (Eds.): El Neógeno de la Mesopotamia argentina. Asociación Paleontológica Argentina, Publicación Especial, 14: 71-83.

Cortes, J.M. 1987. Descripción Geológica de la Hoja 42h, “Puerto Lobos”. Provincia del Chubut. Escala 1:200.000. Dirección Nacional de Minería y Geología, 93 p.

Cozzuol, M.A. 1996. The record of the aquatic mammals in southern South America. Munchner Geowissenschaten Abhandlungen, A30: 321- 342.

Cozzuol, M.A., Tambussi, C., Noriega, J. 1993. Un pingüino (Aves: Spheniscidae) de la Formación Puerto Madryn (Mioceno medio) en Península Valdés, Chubut. Argentina, con importantes implicancias filogenéticas. $10^{\circ}$ Jornadas Argentinas de Paleontología de Vertebrados (La Plata). Resúmenes, Ameghiniana, 30: 327-328

Crampton, J S., Cooper, R., Beu, A.G., Foote, M., Marshall, B.A. 2010. Biotic influences on species duration: interactions between traits in marine molluscs. Paleobiology, 36: 204223. doi.org/10.1666/09010.1 
Cuitiño, J.I., Scasso, R.A., Ventura Santos, R. and Mancini, L.H. 2015. Sr Ages for the Chenque Formation in the Comodoro Rivadavia región (Golfo San Jorge Basin, Argentina): Stratigraphic implications. Latin American Journal of Sedimentology and Basin Analysis, 22: 3-12.

Cuitiño, J. E., Dozo, M.T., del Río, C.J., Buono, M.R., Palazzesi, L., Fuentes, S. Scasso, R.A. 2017. Miocene Marine transgressions: Paleoenvironments and Paleobiodiversity. In: Bouza, P and Bilmes, A. (Eds): Late Cenozoic of Peninsula Valdés, Patagonia, Argentina. An interdisciplinary Approach. Springer Earth System Sciences: 47-84. DOI 10.1007/978-3-319-48508-9_2

Darwin, Ch. 1846. Geological Observations on the volcanic Islands and parts of south America visited during" the voyage of H.M.S. "Beagle", 648 pp. London.

Davila, F.M. 2005 Revisión estratigráfica y paleoambientes del Grupo Angulos (Neógeno), Sierra de Famatina, La Rioja: Su significado en el relleno del antepaís fragmentado. Revista de la Asociación Geológica Argentina, 60: 32-48.

Davila, F.M., Astini, R.A. 2002. Composición de los conglomerados sinorogénicos del Terciario de la Sierra de Famatina y su relación con la fragmentación del antepaís andino central. 9 Reunión Argentina de Sedimentología, Córdoba: 73p.

De Ferraris, C.I.C. 1966. Estudio de la Formación Río Negro de la provincia de Buenos Aires Sus relaciones con la región nordpatagónica. Anales de la Comisión de Investigaciones Científicas, 7: 86 -165. La Plata

del Río, C.J. 1988. Bioestratigrafía y Cronoestratigrafía de Formación Puerto Madryn (Mioceno medio) - Provincia del Chubut, Argentina. Anales de la Academia Nacional de Ciencias Exactas Físicas y Naturales, Buenos Aires, 40: 231-254. 
del Río, C.J. 1991. Revisión sistemática de los Bivalvos de la Formación Paraná (Provincia de Entre Ríos, Mioceno medio) de la Argentina. Academia Nacional de Ciencias Exactas Físicas y Naturales, Buenos Aires, Monografía 7, 93 p.

del Río, C. J. 1992. Middle Miocene Bivalves of the Puerto Madryn Formation (Valdes Peninsule, Chubut Province, Argentina). Through Nuculidae to Pectinidae Part I. Palaeontographica, Abt. A, 225: 1-58.

del Río, C.J., 1994. Middle Miocene Bivalves of the Puerto Madryn Formation (Valdes Peninsule, Chubut Province, Argentina). Through Lucinidae to Pholadidae. Part II. Palaeontographica, Abt. A, 231: 93-132.

del Río, C.J. 2000. Malacofaunas de las Formaciones Paraná y Puerto Madryn (Mioceno marino, Argentina): su origen, composición y significado bioestratigráfico. In: Aceñolaza, F.G. and Herbst, R. (Eds).: El Neógeno de Argentina. Serie Correlación Geológica, 14: 77-101.

del Río, CJ. 2004. Tertiary marine Molluscan Assemblages of Eastern Patagonia (Argentina): a biostratigraphic analysis. Journal of Paleontology, 78: 1097-1122. doi:10.1666/0022-3360(2004)078

del Río, C.J., Martínez, S.A. 1998. El Mioceno marino en la Argentina y Uruguay. In: del Río, C.J. (Ed.): Moluscos marinos miocenos de la Argentina y del Uruguay. Academia Nacional de Ciencias Exactas, Físicas y Naturales, Buenos Aires, Monografía, 15: 5-25.

del Río, C.J., Martínez, S.A., Scasso, R.A. 2001. Nature and origin of spectacular Miocene shell-beds of Northeastern Patagonia (Argentina): Paleoecological and bathymetric Significance. PALAIOS, 16: 3-25. doi: 10.1669/0883-1351(2001)

del Río, C.J. , Griffin, M., Mc Arthur, J., Martinez, S.A., Thirwall, M.F. 2013. Evidence for early Pliocene and late Miocene transgressions in southern Patagonia (Argentina): 
690

691

692

693

694

695

696

697

698

699

700

701

702

703

704

705

706

707

708

709

710

711

712

713

714

${ }^{87} \mathrm{Sr} /{ }^{86} \mathrm{Sr}$ ages of the pectinid “Chlamys” actinodes (Sowerby). Journal of South American Earth Sciences, 47: 220-229. https://doi.org/10.1016/j.jsames.2013.08.004

d’Orbigny, A.D. 1842 . Voyage dans l’ Amerique meridionale (Le Bresil, l’Uruguay exsecute pendant les anne 1826 - 1833. Paleontologie et Geologie , 3 (4):1-152. París.

Dozo, M.T., Bouza, P., Monti, A., Palazzesi, L., Barreda, V., Massaferro, G., Scasso, R.A., Tambussi, C. 2010. Late Miocene continental biota in Northeastern Patagonia (Península Valdés, Chubut, Argentina) Palaeogeography, Palaeoclimatology, Palaeoecology, 297: 100-109. doi:10.1016/j.palaeo.2010.07.018

Eagar, S.H. 2000. Ostracoda in detection of sewage discharge on a Pacific Attol. In: Martin, R.E. (Ed.): Environmental Micropaleontology. New York, Kluwer Ac. Publication., p. 151-165.

Echevarría, A.E., 1988. Ostrácodos marinos de la Formación Río Negro, (Plioceno), Provincia de Río Negro, Argentina. Ameghiniana, 25: 321-340.

Espíndola, V.E. 2004. Analisis preliminar de la microfauna de la Formación San José. Comunicaciones Científicas y Tecnológicas (Universidad Nacional del Nordeste), Resumen: B-042. http://www.unne.edu.ar/unnevieja/Web/cyt/com2004/6-Biologia/B-

\section{$\underline{\text { 042.pdf }}$}

Farinati, E.A., Aramayo, S.A., Terraza, J.C. 1981. La presencia de un nivel marino de la Formación Río Negro (Plioceno superior) Provincia de Río Negro, Argentina. 2 Congreso Latinoamericano de Paleontología (Porto Alegre, Brasil), Anais: 651-665.

Feruglio, E. 1949. Descripción Geológica de la Patagonia. Dirección General de Y.P.F Tomo 2, 349 p.

Figueiras, A., Broggi, J. 1971. Estado actual de nuestros conocimientos sobre los moluscos fósiles del Uruguay. Comunicaciones de la Sociedad de Malacología, Uruguay, 3(21): $131-154$. 
Figueiras, A., Broggi, J. 1973. Estado actual de nuestros conocimientos sobre los moluscos fósiles del Uruguay. Comunicaciones de la Sociedad de Malacología, Uruguay, 3 (2324): 203-240.

Frenguelli, J. 1926. El Entrerriense del Golfo Nuevo en el Chubut. Boletín de la Academia Nacional de Ciencias de Córdoba, 29: 191-270.

Fuentes, S.N., Guler, M.V., Cuitiño, J I., Palazzesi, L., Scasso, R.A., Barreda, D.V. 2016. Bioestratigrafía basada en quistes de dinoflagelados del Neógeno en el noreste de la Patagonia, Argentina. Revista Brasilera de Paleontología, 19: 303-314. doi: 10.4072/rbp.2016.2.12

Gavriloff, I.J.C. 1999. Caracterización de la secuencia parálica neógena del valle de Santa María (Catamarca, Tucumán y Salta; Argentina) y su relación con la ingresión marina paranense. $7^{\circ}$ Simposio Sul Brasileiro de Geologia y $2^{\circ}$ Encontro de Geología do Mercosul (Foz do Iguazu): 77.

Gavriloff, I.J.C., Bossi, G.E. 1992. Revisión general, análisis facial, correlación y edad de las Formaciones San José y Río Salí (Mioceno medio), provincias de Catamarca, Tucumán y Salta, República Argentina. Acta Geológica Lilloana, 17: 5-43.

Groeber, P. 1949 Observaciones geológicas a lo largo del meridiano 70. Adiciones y correcciones. Revista de la Sociedad Geológica Argentina, 4: 37-39.

Gross, M., Ramos, M.I.F., Piller, W.E. 2015. A minute ostracod (Crustacea: Cytheromatidae) from the Miocene Solimões Formation (western Amazonia, Brazil): evidence for marine incursions? Journal of Systematic Paleontology, 14: 581-602. $10.1080 / 14772019.2015 .1078850$

Herbst, R., Zabert, L. 1987. Microfauna de la Formación Paraná (Mioceno superior) de la Cuenca Chaco-Paranense (Argentina). FACENA, 7: 165-206. 
Herbst, R., Anzótegui, L.M., Esteban, G., Mautino, L R., Morton, S., Nasif, N. 2000. Síntesis paleontológica del Mioceno de los valles Calchaquíes, noroeste argentino. In: Aceñolaza, F.G. and Herbst, R. (Eds.): El Neógeno de Argentina. Serie Correlación Geológica, 14: 263-268.

Hernández, R.M., Jordan, T E., Dalenz Farjat, A., Echavarría, L., Idleman, B.D., Reynolds, J. H. 2005. Age, distribution, tectonics, and eustatic controls of the Paranense and Caribbean marine transgressions in southern Bolivia and Argentina. Journal of South American Earth Sciences, 19: 495-512. doi:10.1016/j.jsames.2005.06.007

Hovikosky, J.M, Räsänen, M., Gingras, M., Lopez, S., Romero, L., Ranzi, A., Melo, J. 2007. Paleogeographical implications of the Miocene Quedenque Formation (Bolivia) and tidally-influenced strata in southwestern Amazonia. Palaeogreography, Palaeoclimatology, Palaeoecology, 243: 23-41. doi:10.1016/j.palaeo.2006.07.013

Hulka, C., Gräfe, K.U., Sames B. Uba, C.E., Heubeck, C. 2006. Depositional setting of the Middle to Late Miocene Yecua Formation of the Chaco Foreland Basin, southern Bolivia. Journal of South American Earth Sciences, 21: 135-150. https://doi.org/10.1016/j.jsames.2005.08.003

Ihering, H. von. 1927. Die Geschichte des Atlantischen Ozeans, 237 pp. Fischer, Lena.

Jordan, T.E., Tamm, V., Figueroa, G., Flemings, P.B., Richards, D., Tabbutt, K., Cheatham, T. 1996. Development of the Miocene Manantiales foreland basin, Principal Cordillera, San Juan, Argentina. Revista Geológica de Chile, 23: 43-79.

Karanovic, I. 2008. Three interesting Cyprididae (Ostracoda) from Western Australia. Records of the Western Australian Museum, 24: 267-287. doi :10.18195/issn.0312-3162.

Keyser, D. 1977. Ecology and zoogeography of Recent brackish water Ostracoda (Crustacea) from south-west Florida. In: Löffler, H. and Danielopol, D. (Eds): Aspects of 
ecology and zoogeography of Recent and fossil Ostracoda, pp. 207v222. Dr. W. Junk Publisher, The Hague, Netherlands

Leiva, G.C., Morton, S. 2001. Ostrácodos de la Formación San José (Mioceno), Provincias de Catamarca y Tucumán. http://www.unne.edu.ar/unnevieja/Web/cyt/cyt/2001/6-

\section{Biologicas/B-010.pdf}

Malumián, N. 1970. Bioestratigrafía del Terciario marino del subsuelo de la Provincia de Buenos Aires (Argentina). Ameghiniana, 7:173-204.

Malumián, N. 1978. Esbozo paleoecológico de las asociaciones foraminiferológicas terciarias de la Argentina. Ameghiniana, 15: 161-171.

Malumián, N. 1999. La sedimentación en la Patagonia Extrandina. Anales del Servicio Geológico Minero Argentino, 29: 557-578.

Malumián, N., Nañez, C. 1996. Microfósiles y nanofósiles de la Plataforma continental. In: Ramos, V.A. and Turic, M.A. (Eds.): Geología y Recursos Naturales de la Plataforma continental argentina. $13^{\circ}$ Congreso Geológico de Hidrocarburos (Buenos Aires), Relatorio: 73-94.

Malumián, N., Nañez, C. 2011. The Late Cretaceous-Cenozoic transgressions in Patagonia and the Fuegian Andes: foraminifera, palaeoecology, and palaeogeography. Biological Journal of the Linnean Society, 103:269-288. doi:10.1111/j.1095-8312.2011.01649

Malumián, N., Olivero, E.B. 2006. El Grupo Cabo Domingo, Tierra del Fuego: bioestratigrafía, paleoambientes y acontecimientos del Eoceno-Mioceno marino. Revista de la Asociación Geológica Argentina, 61: 139-160.

Marengo, H.G. 2000. Rasgos micropaleontológicos de los depósitos de la transgresión Entrerriense-Paranense en la cuenca Chaco-Paranense y Noroeste Argentino. In: Aceñolaza, F.G. and Herbst, R. (Eds.): El Neógeno de Argentina. Serie Correlación Geológica, 14: 14: 29-45. 
788

789

790

791

792

793

794

795

796

797

798

799

800

801

802

803

804

805

806

807

808

809

810

Marengo, H.G. 2015. Neogene micropaleontology and stratigraphy of Argentina. The Chaco

- Paranense Basin and the Península de Valdés. Springer Briefs in Earth Systems Sciences. South America and the Southern Hemisphere, 218 pp. doi:10.1007/978-3-319-

\section{$12814-6$}

Marengo, H.G., Concheyro, A. 2001. Foraminiferos y nanofósiles calcáreos del subsuelo de la ciudad de Buenos Aires y alrededores. $11^{\circ}$ Congreso Latinoamericano de Geología y $3^{\circ}$ Congreso Uruguayo de Geología, Montevideo, Actas, CD.

Marshall, L.G., Sempere, T., Gayet, M. 1993. The Petaca (Late Oligocene-Middle Miocene) and Yecua (Late Miocene) formations of the Subandean-Chaco Basin, Bolivia, and their tectonic significance. Laboratoire de Géologie de Lyon, 125: 291-301.

Martínez, S.A. 1989. Los depósitos de la “transgresión entrerriana” (Mioceno de Argentina, Brasil y Uruguay). Comparación de sus principales áreas fosilíferas a través de los bivalvos y los gastrópodos. Ameghiniana, 25: 23-29.

Martínez, S.A. 1994. Bioestratigrafía (Invertebrados) de la Formación Camacho (Mioceno, Uruguay). PhD Thesis, 346 p. Facultad de Ciencias Exactas y Naturales, Universidad de Buenos Aires.

Martínez, S.A., del Río, C.J. 2002. Late Miocene Molluscs from the Southwestern Atlantic Ocean (Argentina and Uruguay): a paleobiogeographic analysis. Palaeogeography, Palaeoecology, Palaeoclimatology, 188 (3 - 4): 167-187.

Martínez, S.A., del Río, C.J. 2005. Las ingresiones marinas del Neógeno en el sur de Entre Ríos (Argentina) y litoral oeste de Uruguay y su contenido malacológico. In: Aceñolaza, F. (Ed.): Temas de la Biodiversidad del litoral fluvial argentino II. INSUGEO, Miscelánea, 14: 13-26 
McArthur, J.M., Howarth R.J., Shields G.A. 2012. Strontium Isotope Stratigraphy. In: Gradstein FM, Ogg J.G., Schmitz M.D. and Ogg G.M. (Eds.): The Geologic Time Scale, Vol 1 of 2, Chapter 7, 1144 pp. Elsevier,

Morton, S., Herbst, R. 2003. Moluscos dulceacuícolas de las Formaciones San José y Chiquimil (Mioceno) del Valle de Santa María (Catamarca y Tucumán), Argentina. Ameghiniana, 40: 205-216.

Nicolaides, D.D., Coimbra, J.C. 2008. Perissocytheridea carrenoae sp. nov. (Crustacea, Ostracoda) and associated calcareous microfauna from Yecua Formation (Miocene), Bolivia. Revista Brasileira de Paleontología, 11:179-186. doi: 10.4072/rbp.2008.3.04

Nutall, C.P. 1990. A review of the Tertiary non-marine molluscan faunas of the Pesbian and other inland basins of north-western South America. Bulletin of the British Museum of Natural History (Geology), 45:165-371.

Ottone, E.G., Barreda, V D., Perez, D.J. 1998. Basin evolution as reflected by Miocene palynomorphs from the Chinches Formation, Frontal Cordillera (32 S), San Juan Province, Argentina. Revista Española de Micropaleontología, 30: 35-47.

Palazzesi, L., Barreda, V.D. 2004. Primer registro palinológico de la Formación Puerto Madryn, Mioceno de la provincia del Chubut, Argentina. Ameghiniana, 41:355-362.

Palazzesi, L. Barreda, V.D, Cuitiño, J.I., Guler, M.V., Tellería, M.C., Ventura Santos, R. 2014. Fossil pollen records indicate that Patagonian desertification was not solely a consequence of Andean uplift. Nature Comunications. doi: 10.1038/ncomms4558.

Parras, A., Dix, G. R., Griffin, M. 2012. Sr-isotope chronostratigraphy of Paleogene Neogene marine deposits: Austral Basin, southern Patagonia (Argentina). Journal of South American Earth Sciences, 37: 122-135. https: //doi.org/10.1016/ j.jsames.2012.02.007 
Pascual, R., Ortiz Jaureguizar, E., Prado, J.L. 1996. Land mammals: paradigm for Cenozoic South American geobiotic evolution. In: Arriata, G. (Ed.): Contribution to Southern South America to Vertebrate Paleontology. Múnchner Geowissenschaftliche Abhandlungen, (A), 30: 265-319.

Perea, D. 2005. Pseudoplohophorus absolutus n. sp. (Xenarthra, Glyptodontidae), Sclerocalyptinae. Variability and a biozone redefinition from the Upper Miocene of Uruguay. Ameghiniana, 42: 175-190.

Perea, D., Ubilla, M. 1989. Selacifauna del Mioceno Superior del Uruguay. Boletín de la Sociedad Zoológica de Uruguay (2ª Epoca), 5: 11-12.

Perea, D., Ubilla, M. 1990. Los selacios (Chondrichthyes) de la Formación Camacho (Mioceno superior) Uruguay. Revista de la Sociedad Uruguaya de Geología, 4: 5-13.

Perea, D., Ubilla, M., Martínez, S., Piñeiro, G., Verde, M. 1994. Mamíferos Neógenos del Uruguay: la edad-mamífero Huayqueriense en el "Mesopotamiense”. Acta Geológica Leopoldensia, 17, (39/1): 375-389.

Perea, D., Rinderknecht, A., Ubilla, M., Bostelmann, E., Martínez, S. 2013. Mamíferos y estratigrafía del Neógeno de Uruguay. Asociación Paleontológica Argentina, Publicación Especial,14: 186-200.

Perez, D.J., Ramos, V.A. 1996. Los depósitos sinorogénicos. In: Ramos, V.A. (Ed.): Geología de la región del Aconcagua, provincias de San Juan y Mendoza. Dirección Nacional del Servicio Geológico, Anales 24 (11): 317-341.

Pérez, L.M. 2013. Nuevo aporte al conocimiento de la edad de la Formación Paraná, Mioceno de la Provincia de Entre Ríos, Argentina. In: Noriega, J. and Brandoni, D. (Eds.): El Neógeno de la Mesopotamia argentina. Asociación Paleontológica Argentina, Publicación Especial, 14: 56-70 
Petuch, E.J. 1988. Neogene History of Tropical American Molluscs: Biogeography and Evolutionary Patterns of Tropical Western Atlantic Mollusca, The Coastal Education and Research Foundation, Charlottesville, Virginia, 217 pp.

Petuch, E. J. 2014. Cenozoic Seas. The View from Eastern North America. CRC Press, Boca Ratón. 308 pp.

Quatrocchio, M., Durango de Cabrera, J., Galli, C. 2003 Formación Anta (Mioceno Temprano/Medio), Subgrupo Metán (Grupo Orán), en el río Piedras, Pcia. de Salta. Revista de la Asociación Geológica Argentina, 58: 117-127.

Ramos, V.A., Alonso, R.N. 1995. El Mar Paranense en la provincia de Jujuy. Revista del Instituto de Geología y Minería, 10: 73-82.

Räsänen, M.T., Linna, A.M., Santos, J.C.R., Negri, F.R. 1995. Late Miocene tidal deposits in the Amazonian Foreland Basin. Science, 269: 386-390

Reynolds, J.H., Galli, C.I., Hernández, R.M., Idleman, B.D., Kotila, J.M., Hilliard, R.V., Naeser, C.W. 2000. Middle Miocene tectonic development of the Transition Zone, Salta Province, northwest Argentina: magnetic stratigraphy from the Metán Subgroup, Sierra de González. Geological Society of America, Bulletin, 112: 1736-1751.

Riva Rossi, C.M. 1997. Una nueva especie del genero Genypterus (Pisces, Ophidiiformes) del Mioceno medio de Península Valdes (Chubut) y sus relaciones filogenéticas con los abadejos actuales. $12^{\circ}$ Jornadas Argentinas de Paleontología de Vertebrados (La Pampa), Resúmenes: 68.

Rossi de García, E. 1966. Contribución al conocimiento de los ostrácodos de la Argentina. I Formación Entre Ríos, de Victoria. Provincia de Entre Ríos. Revista de la Asociación Geológica Argentina, 21: 194-208.

Roth, S. 1908. Beitrag zur Gliederung der Sedimentablagerungen in Patagonien und der Pampasregion. Neues Jahrbuch für Geologie and Paläontologie, B26: 92-150. 
884

885

886

887

888

889

890

891

892

893

894

895

896

897

898

899

900

901

902

903

904

905

906

907

Ruskin, B.G., Dávila, F.M., Hoke, G.D., Jordan, T.E., Astini, R.A, Alonso, R. 2011. Stable isotopes composition of middle Miocene carbonates of the Frontal Cordillera and Sierras Pampeanas: Did the Paranense seaway flood western and central Argentina? Palaeogeography, Palaeoclimatology, Palaeoecology, 308: 293-303. doi:10.1016

\section{/j.palaeo.2011.05.033}

Russo, A., Serraiotto, A. 1978. Contribución al conocimiento de la estratigrafía terciaria en el noroeste argentino. $7^{\circ}$ Congreso Geológico Argentino (Nuequen), Actas, 1: 715-730.

Scasso, R.A., del Río, C.J. 1987. Ambientes de Sedimentación y Proveniencia de la Secuencia marina del Terciario superior de la península Valdes. Revista de la Asociación Geológica Argentina, 42: 291-321.

Scasso, R.A., McArthur, J. M., del Río, C.J., Martínez, S.A., Thirlwall M. F. $2001 .{ }^{87} \mathrm{Sr} /{ }^{86} \mathrm{Sr}$ Late Miocene age of fossil molluscs in the "Entrerriense” of Valdés Península (Chubut, Argentina). Journal of South American Earth Sciences, 14: 319-329.

Sprechmann, P., Aceñolaza, F.G. 1999. Correlación paleoecológica y sedimentológica de las Formaciones Paraná (Argentina) y Camacho (Uruguay) del Mioceno Medio a Superior. $1^{\circ}$ Jornadas del Cenozoico del Uruguay, Actas: 25-26.

Sprechmann, P., Gaucher, C., Frei, R. 2010. Identificación del Burdigaliense (Mioceno temprano) en ostreidos procedentes de afloramientos de la Formación Camacho de Uruguay datados con ${ }^{87} \mathrm{Sr} /{ }^{86} \mathrm{Sr}$. $10^{\circ}$ Congreso Argentino de Paleontología y Bioestratigrafía y $7^{\circ}$ Congreso Latinoamericano de Paleontología, (La Plata), Actas, 1: 106.

Stappenbeck, R. 1926 . Geologie und GrundwasserKunde der Pampa. 409 p. Stuttgart

Tapia, A. 1937. Datos geológicos de aguas minerales de la República Argentina. 2 Provincia de Buenos Aires. Ministerio del Interior, Comisión Nacional de Climatología y Aguas Minerales, 23-90 p. 
Tineo, D.E., Bona, P. Pérez, L.M. ,Vergani, G.D., González, G., Poiré, D.G., Gasparini, Z., Legarreta, P. 2015. Palaeoenvironmental implications of the giant cocodrylian Mourasuchus (Alligatoridae, Caimaninae) in the Yecua Formation (late Miocene) of Bolivia. Alcheringa, 39: 224-235. dx.doi.org/10.1080/03115518.2015.967162

Uba, C.E., Hasler, C., Buatois, L.A., Schmitt, A.K., Plessen, B. $2009 . \quad$ Isotopic, paleontologic, and ichnologic evidence for late Miocene pulses of marine incursions in the central Andes. Geology, 37 (9): 827-830. doi: 10.1130/G30014A.1

Uliana, M.A., Biddle, K.T. 1988. Mesozoic-Cenozoic paleogeographic and geodynamic evolution of Southern South America. Revista Brasilera de Geociencias, 18: 172-190.

Vergani, G., Decastelli, O., Moroni, Chaia, A. 1991. Análisis estratigráfico y diagenético del Mioceno del valle de Santa María, provincias de Salta, Tucumán y Catamarca. YPF S.A. Informe inédito, 27 pp.

Webb, S.D. 1995. Biological implications of the middle Miocene Amazon Seaway. Science, 269: 361-362.

Windhausen, A. 1931. Geología Argentina. Geología histórica y regional del territorio argentino. Part 2, Peuser, Buenos Aires, 645 pp.

Yrigoyen, M.R. 1969. Problemas estratigráficos del Terciario de Argentina. Ameghiniana, $6: 315-329$.

Yrigoyen, M.R. 1975. Geología del subsuelo y plataforma continental. $6^{\circ}$ Congreso Geológico Argentino, ((Bahía Blanca), Relatorio: 139-168.

Yrigoyen, M.R. 1993. Los depósitos sinorogénicos terciarios. 12 Congreso Geológico Argentino y $2^{\circ}$ Congreso de Exploración de Hidrocarburos (Mendoza), Relatorio: 1 (11): $123-148$

Zabert, L.L. 1978. Micropaleontología de la Formación Paraná (Mioceno superior) en el subsuelo de la provincia de Santa Fe, República Argentina. FACENA 2: 101-165. 
933

934

935

936

937

938

939

940

941

942

943

944

945

946

947

948

949

950

951

952

953

954

955

956

957
Zabert, L.L., Herbst, R. 1977. Revisión de la microfauna miocena de la Formación Paraná (entre Victoria y Villa Urquiza, Provincia de Entre Ríos, Argentina) con algunas consideraciones estratigráficas. FACENA, 1: 131-174.

Zinsmeister, W.J., Marshall, L.G., Drake, R.E., Curtis, G.H. 1981. First Radioisotope (Potassium-Argon) Age of marine Neogene Rionegro beds in northeastern Patagonia, Argentina. Science, 212 (4493): 440.

9


960 Figure 1 A - Paleogeography of the late Miocene "Paranense" Sea (dotted line), exposures of 961 the studied sedimentites (in orange) and location of measured lithological sections: 1- Cueva 962 Los Leones; 2- Punta Logaritmo; 3- Salina Grande; 4- Bahía Cracker; 5- Balneario La 963 Lobería; 6- Riachuelo IV; 7- Paraná; 8- Punta Gorda; 9- Cantera Geymonat. B964 Paleogeography of the "Patagoniense" Sea and eastern exposures of lithological units 965 mentioned in the text. C- Enlargment of Northern coast of the San Matías Gulf. D966 Geographic location of the study sites in Península Valdes.

967 Figure 2 - Chronostratigraphic chart of deposits of the "Patagoniense" and "Paranense” seas 968 on Eastern Patagonia based on isotopic data calculated by: 1-Parras et al., (2012), 2- Cuitiño 969 et al. (2015); 3- del Río et al. (2013); 4- this paper; 5- Palazzesi et al. (2014) (D) no isotopic 970 data available for these units. Abbreviations: $\mathrm{PP}=$ Panopea sierrana-Parinomya patagonensis 971 Assemblage; RSP=Reticulochlamys zinsmeisteri-Struthiolarella patagoniensis- Pleuromeris 972 cruzensis Assemblage; JR= Jorgechlamys centralis-Reticulochlamys borjasensis Assemblage; 973 NVG= Nodipecten sp.-Venericor abasolensis-Glycymerita camaronesia Assemblage; M$974 \mathrm{M} / \mathrm{R}=$ Multisiappolis viteauensis-Margocolporites tenuireticulatus - Reticulatosphaera? 975 actinocoronata Assemblage; C-T/L= Cypereaceaepollis neogenicus-Tricolpites triloblatus 976 /Lingulodinium hemicystum Assemblage; G/C= Glencopollis ornatus/ Cannosphaeropsis 977 utinensis Assemblage

978 Figu Lithological sections of the studied "Paranense" deposits. Mean ages in red.

979 Figure 4- Exposures of the "Paranense” deposits. A-C- Facies Balneario La Lobería at 980 Balneario la Lobería (Viedma, Río Negro); D-E- Regressive Phase of the Puerto Madryn 981 Formation at Salina Grande and detail of the uppermost fossiliferous bed (Península Valdés, 
982 Chubut); F- Panoramic view of Gaiman and Puerto Madryn formations at Punta Logaritmo 983 (Peninsula Valdés, Chubut); G-H- Panoramic view of Camacho Formation at Cantera 984 Geymonat and detail of fossiliferous accumulation (Colonia, Uruguay); I-J -Exposure of the 985 Paraná Formation and detail of shell-bed (Punta Gorda, Entre Ríos). White arrow indicates the 986 procedence of the material dated herein.

987 Figure 5-A- ${ }^{87} \mathrm{Sr} /{ }^{86} \mathrm{Sr}$ numerical ages clustered into five groups. Gromps 1,2 and 3 are 988 stratigraphically coherent with the Transgressive (1) and Regressive Phases (2 and 3) of the 989 Puerto Madryn Formation expqead at Cueva Los Leones and Peninsula Valdés; B- Numerical 990 ages obtained by Scasso et al. (2001)

991 Table 1- Values of ${ }^{87} \mathrm{Sr} /{ }^{86} \mathrm{Sr}$ in 20 samples of Aequipecten paranensis from the "Paranense" 992 sedimentary deposits. 